\title{
Choosing between civil contract and employment contract
}

\author{
Raluca Dimitriu ${ }^{\mathrm{a}, 1}$ \\ ${ }^{\text {a }}$ The Bucharest University of Economic Studies, Romania
}

\begin{abstract}
The requalification of the civil contract as an employment contract is the work of unlocking its true legal nature, thus removing the improper (or deliberately misleading) terms used by the parties and revealing the true understanding between them. The requalification can be performed by a fiscal control body, as representative of the third party - namely the state - damaged by the non-payment of contributions and fees, according to the true legal nature of the relationship between the parties. The requalification can be performed by a labour control body, which seeks to eliminate the risk of undeclared work and prevents the employer from abusing the worker. Or it can be carried out by the courts themselves, most often at the request of the worker, who seeks to open the way for the benefits deriving from the protective rules of labour law, inaccessible to the worker who concludes a mere civil contract. The current set of regulations on requalification of the employment contract is far from ideal. Therefore, a number of improvements to ensure coherence in the system would be welcome. The paper aims to identify the relation between the current rules in civil law, labour law, and fiscal law and to include some de lege ferenda proposals in order to make the Romanian legislation more prepared to fight against undeclared work, by still observing the parties right to freely contract.
\end{abstract}

Keywords: Labour law, civil contract, employment contract, requalification, labour inspection

\section{JEL codes: K31}

\footnotetext{
${ }^{1}$ raluca.dimitriu@cig.ase.ro, University of Economic Studies, Bucharest, Romana Square no 6, Romania. The paper has been presented at the $13^{\text {th }}$ edition of the International Conference Accounting and Management Information Systems (AMIS 2018), on June $13-14,2018$
} 


\section{Introduction}

An individual employment contract is decisively characterized by the relationship of subordination between the parties, which fundamentally distinguishes it from the civil contract. The employment contract is not a civil relationship between two peers; on the contrary, it is a contract characterized by a democratic deficit which only the legislative intervention can limit, restoring, even in part, the balance between the contracting parties. However, the employment contract is not the only contract under which work is performed, but there are also civil contracts under which one of the parties carries out an activity for the benefit of the other party who pays it. As a result, the parties may obscure the nature of employment contract of the relationship between them, disguising it in a civil contract.

This paper highlights the different ways in which the true intent of the parties can be unveiled. We will analyze the case in which the true legal nature of the contract is put into light by the court, by the fiscal control bodies, or by the labor inspectorates. Each of these bodies has its own instruments to requalify the contract between the parties. As the mechanisms differ, often the results of the requalifying the contract may differ, and sometimes the outcome may be surprisingly far from the text of the contract. The paper is the result of the analysis of the recent jurisprudence in the matter, as well as of the decisions of the control bodies.

And indeed, the requalification of the civil contract as an employment contract is the work of unlocking its true legal nature, thus removing the improper (or deliberately misleading) terms used by the parties and revealing the true understanding between them. The requalification can be performed by a fiscal control body, as representative of the third party - namely the state - damaged by the non-payment of contributions and fees, according to the true legal nature of the relationship between the parties.

The requalification can be performed by a labour control body, which seeks to eliminate the risk of undeclared work and prevents the employer from abusing the worker. Or it can be carried out by the courts themselves, most often at the request of the worker, who seeks to open the way for the benefits deriving from the protective rules of labour law, inaccessible to the worker who concludes a mere civil contract.

\section{Requalification of the contract by the courts}

For a worker, the conclusion of a civil contract in place of an employment one can be either an error or the result of a simulated agreement with the purpose of, for example, defrauding the interests of creditors - that is, the state budget, by failing to pay the contributions due. Therefore, the worker is most often the one who 
lodges a claim to requalify the contract and to have his employee status recognized. He will do so when realising that, by concluding the civil contract, he was deprived of a number of benefits to which he would have been otherwise entitled.

Unlike other systems of law (Daugareilh, 2011: 66), our legal system does not include specific labour law instruments to disclose such disguised labour contracts. If we use conceptual tools specific to civil law, we could say that this legal operation has the legal configuration of an objective relative simulation through total disguise (Baias, 2003: 128). Thus, three contracts are concluded between the parties:

a) a real, but secret employment contract. Although the parties agree in principle that the worker will have the exact legal position of an employee, they do not (usually) conclude a contract of employment as such, even less in written form;

b) a simulated agreement. By this, the parties agree that the public act should consist of a civil contract. The mediated cause of this agreement may be to defraud the interests of creditors - i.e. the state budget or the social security budget, by not paying the contributions due - as well as to render the protective norms of labour law (the minimum wage, holidays, collectively negotiated rights, etc.) inapplicable. Often such an escape from the protective umbrella of labour law is at the expense of the worker; the acceptance of such a simulated agreement takes place by defective consent (for example, through error of law or violence). Therefore, the worker's consent to the conclusion of the simulated agreement may be vitiated;

c) a public but fake civil contract. It could be a service contract or even a voluntary contract. With respect to the latter, art. 10 para. (1) of Volunteering Law no. 78/2014 provides that "it is forbidden, under the sanction of nullity, to conclude a voluntary contract in order to avoid the conclusion of an individual employment contract or, as the case may be, a civil service contract or other civil contract for consideration for the performance of those activities". However, the text is not very helpful, because it only mentions the cancellation of the voluntary contract, and not the conditions under which the contract of employment disguised as a voluntary contract could be considered valid.

The court competent to reclassify such a contract and to declare the status of employee is the labour law court, not the civil law court, although art. 1 lit. p) of the Social Dialogue Law no. 62/2011 (republished in the Official Gazette of Romania, Part I, no. 625 of 31 August 2012) does not explicitly mention this action among the tasks of labour law courts.

But during the 2011-2017 period, the requalification of the employment contract was confronted with an additional difficulty, namely the difficulty of admitting the evidence with witnesses or other types of evidence in proving a solemn contract. It was because the employment contract was devoid of its consensual character (traditional and universal), and in order to have juridical effects, it had to be 
concluded in writing. Consequently, even if the employee had brought an action for the recognition of the status of employee and the contract he had concluded, although called a civil contract, had the characteristics of an employment contract, it was not clear if such an action were admissible.

In order to resolve this situation, clearly unfavourable to the employee, the High Court of Cassation and Justice intervened by Decision 37/2016 (published in the Official Gazette of Romania, Part I, No. 114 of 10 February 2016), considering that such an action is admissible. The court's decision was innovative, in the legal literature there were even remarks that it "adds to the law" (Ştefănescu, 2017: 284).

By Government Emergency Ordinance no. 53/2017 (published in the Official Gazette of Romania, Part I, No. 633 of 7 August 2017) the consensual character of the employment contract returned, in parallel with the increase of the fines for lack of written form, as already suggested in the legal literature (Dimitriu, 2016: 49). Naturally, the fact that a contract of employment is consensual does not mean that its verbal conclusion is allowed. On the contrary, the validity of the verbal contract does not exclude the administrative sanction issued by the control body, because the failure to conclude it in writing - and furthermore to register the contract in the Employee Register, draws the applicability of fines of 20,000 lei.

Therefore today's legal regime returned to that prior to 2011, when the existence of an employment contract could be proved easier. Although we must point out that even before the written form as a condition for the validity of the employment contract was imposed, the courts had decided, for example, that "the involvement of a person in the activity of his employed wife, for the selling of goods, constitutes a voluntary activity and is not an activity in the benefit of the employer" (Rotaru \& Cristescu, 2011: 6). And also in the legal literature it has been hold that "whenever it is found that work is done regularly and in return for remuneration, the legal relationship should be appreciated as being a labour relation" (Gheorghe, 2013: 229).

We consider that labour law courts could successfully use the criteria set out in Recommendation no. 198/2006 of the International Labour Organization - in the identification of the employment contract and in distinguishing it from a civil contract (regarding the implementation of this recommendation in the law of European states, ILO, 2013: 28-52).

According to this recommendation, Members should consider the possibility of defining in their laws and regulations, or by other means, specific indicators of the existence of an employment relationship. Those indicators might include:

- the fact that the work: is carried out according to the instructions and under the control of another party; involves the integration of the worker in the 
organization of the enterprise; is performed solely or mainly for the benefit of another person; must be carried out personally by the worker; is carried out within specific working hours or at a workplace specified or agreed by the party requesting the work; is of a particular duration and has a certain continuity; requires the worker's availability; or involves the provision of tools, materials and equipment by the party requesting the work;

- periodic payment of remuneration to the worker; the fact that such remuneration constitutes the worker's sole or principal source of income; provision of payment in kind, such as food, lodging or transport; recognition of entitlements such as weekly rest and annual holidays; payment by the party requesting the work for travel undertaken by the worker in order to carry out the work; or absence of financial risk for the worker (Dimitriu, 2015: 75-76).

These criteria are not, however, abstract; they have to be applied on a case-by-case basis (Daubler, 2011: 132-133). If an application to determine the existence of an employment contract is filed with a Romanian court, the judge could also analyze the reality of the relationship between the parties according to the criteria set out in Recommendation no. 198/2006, without requiring the worker to provide evidence of the secret contract or the simulated agreement, but rather to assess to what extent the criteria indicated correspond to the actual contract between the parties.

However, these are not legal criteria. They are not found anywhere in Romanian legislation in force. Therefore, the labour law judge could also focus on another set of criteria, legal this time, albeit not included in labour law, but in tax law. This set of criteria, listed in art. 7 point 3 of the Fiscal Code - Law no. 227/2015 (published in the Official Gazette of Romania, Part I, No. 688 of 19 September 2015), is used to identify independent work. Per a contrario, it follows that failure to meet these criteria would indicate the dependent nature of the activity performed by the worker.

But the labour law court is in no way bound to follow the criteria of the Fiscal Code. Nor do these criteria explicitly concern the determination of the legal nature of the contract, but merely the appraisal of the income earned by the worker from dependent activity.

Of course, the starting point is the name given by the parties. It is only by proof to the contrary that it can be concluded that this name does not correspond to the reality of the relationship between them. "The real will - it has been shown - must be proven. Until this evidence, the manifestation - the declaration - of will, the form in which it is presented, is the only proven reality: until the contrary, it is considered to correspond fully to the real will" (Stătescu \& Bîrsan, 1981: 71). 


\section{Requalification of the contract by the control authorities}

Revenue can be requalified as salary income by the fiscal control body, as the contract itself can be requalified as an employment contract - by the territorial labour inspectorate. And indeed, "sometimes the employment relationship is objectively ambiguous, some other times it is deliberately disguised" (Rosioru, 2012: 19).

Thus, even if a contract of employment was concluded as a civil contract, there are a number of criteria laid down by the Fiscal Code - Law no. 227/2015, in relation to which it can be requalified, taking into account the substance of the relations between the parties and not the title assigned by them to the concluded contract. Thus, even if the parties designate the contract as a service contract or a collaboration agreement, if it appears from the content that it is an "employment relationship" - the fiscal control bodies will be able to reconsider the revenues obtained on the basis of the contract as salary income. The consequence of this requalification will be the possibility of setting contributions at the level due in the case of an employment contract.

According to art. 7 (3) of the Fiscal Code, independent activity is an activity carried out by a natural person for the purposes of obtaining income, if it meets at least four of the following conditions:

- the natural person is free to determine the place and the way to carry out the activity, as well as the work schedule;

- the natural person is free to work for more than one client;

- the natural person performs tasks (under their own responsibility) bearing the risk of the activity;

- the activity is carried out by using the patrimony of the natural person who performs it;

- the activity is performed by the natural person by using the intellectual capacity and/or physical performance, depending on the type of activity;

- the natural person belongs to a professional body/order with the role of representing, regulating and supervising the profession, according to special normative acts regulating the organization and the exercise of the respective profession;

- the natural person has the freedom to carry out the activity directly, with employed personnel or by contracting third parties under the law.

These criteria are not provided by labour law but by tax law, and the purpose of requalifying the contract is not to protect the rights of the person performing the work and the application of the regime established by the Labour Code but to retroactively pay the contributions owed to the state by the parties and the applicability of the rules of social security law. 
The criteria listed in the Fiscal Code, though not perfect, are nevertheless useful, as the only legal criteria that could be used in reclassifying a civil contract as employment. Labour law courts might consider them in cases concerning the determination of an employment relationship in correlation with the criteria laid down by the Recommendation of the International Labour Organization. Moreover, if a contract has already been requalified by the fiscal control body, and the worker asks the labour court to ascertain the existence of an employment contract, the court may look carefully into the decision of the tax authorities. Reclassifying income as salary does not automatically entail the requalification of the contract as employment but it constitutes a supposition that only clear evidence in favour of the civil legal nature of the contract (in particular, as noted, by the test of legal equality between the contracting parties) could remove.

Indeed, if the tax authority decided to reclassify the income earned by a worker, considering that it is salary income and required the payment of contributions corresponding to that reclassification, the person who has obtained that income would be also interested in enjoying the benefits associated with the status of employee, since he has paid the appropriate dues. According to Government Emergency Ordinance no. 79/2017, published in the Official Gazette no. 885 of 10 November 2017, the social and health insurance contributions are paid mainly by the employee.

However, the possibility that the fiscal control body - and in the event of a challenge, the tax jurisdiction court - opts for the reclassification of the income obtained as salary while the labour law court finds that the legal nature of the contract is nonetheless that of employment can not be ruled out. Indeed, the tax inspection body does not have the power to rule on the legal nature of the contract; it can only proceed to reclassify the earnings obtained on its basis. As noted, the Fiscal Code does not even use the terms "employment contract" or "employee", but only "employment relationship" and "income beneficiary".

In practice, the High Court of Cassation and Justice - Administrative and Tax Appeals Division had the opportunity to rule on the requalification carried out by the fiscal control bodies by Decision no. 4.767/2011, when deciding on the legal relationship of professional athletes: "It is noted that the fiscal control body has correctly observed that the activity of the football player is not carried out intermittently and occasionally and does not meet the legal criteria for being selfemployment. In this situation, the earnings of the players were correctly reclassified as salary income and are not the result of an independent activity involving the participation of athletes in competitions on their own, without contractual relations with the paying entity, by the free choice of activity, program and venue of the activity. (...) The tax inspection body has reclassified the income earned by professional athletes, coaches and administrative staff as salary according to the law. As a result of the requalification of income earned by athletes 
and coaches as income from salaries, the tax inspection bodies recalculated the tax base related to this income, correctly establishing the payment by the applicantrespondent of amounts representing additional differences and accessories related to additional fiscal obligations in accordance with the applicable fiscal legislation in force." It is noted that a fiscal court reclassifies the income, not the contract itself; with regard to the legal nature of the latter, only the labour law court will be able to decide.

However, with regard to the competence to requalify, a Government Decision adopted last year draws attention by its effects. Government Decision no. 488/2017 regarding the approval of the Regulation for the organization and functioning of the Labour Inspection (published in the Official Gazette of Romania, Part I, No. 594 of 25 July 2017) provides in art. 12 para. (1) B. that Labour Inspection has, inter alia, the following tasks:

"d) determines whether the activity performed under a contract other than employment contract is carried out under an employment relationship;

e) orders the conclusion of individual employment contracts and their recording in the General Register of Employees for the workers identified as performing activities without an individual employment contract".

These tasks have been introduced in the wider context of multiplying the methods of fighting undeclared work; Government Emergency Ordinance no. 53/2017, which amended the Labour Code, would enter into force after only one month, including a broader definition of undeclared work and more severe sanctions.

Therefore, the labour inspector will be able to decide on the very legal nature of the contract concluded by the parties, ascertaining that it corresponds to an employment relationship. However, the criteria for doing so are not provided, as the effects of such requalification are not foreseen. Since work performed under a contract of employment not concluded in writing (Art. 151 (a) of the Labour Code), or written but not registered (Art. $15^{1}$ (b) of the Labour Code) constitutes undeclared work, it follows that work carried out under an employment relationship, but based on a contract with a different denomination is also undeclared work. After requalification of the contract as employment, the labour inspector could apply administrative fines for undeclared work.

However, the problem is this: based on which criteria the labour inspector finds that "the activity performed under a contract other than employment contract is carried out under an employment relationship"? As we have seen, establishing the characteristics of an employment relationship is performed with a very fine balance, taking into account many nuances while the employment nature of a legal relationship is not immediately visible. Since there are no legal criteria, it is difficult to understand exactly how labour inspectors will actually achieve such requalification. 
But the second task among those cited raises even more difficulties. Thus, the labour inspector is called upon to request the conclusion of a contract. We think it concerns the conclusion of the contract as instrumentum, namely a written contract, because in the sense of negotium it will already have been concluded, since the inspector has identified workers performing activities in the respective workplace. But how could a third party impose on the parties the conclusion of the contract? The employer, who unlawfully employed workers without complying with the formalities required by the Labour Code may of course be obliged to pay the corresponding administrative fine. But he may refuse to conclude in the future a written contract with the person performing undeclared work, because by committing a contravention he will not lose the right to the exercise freedom of contract. Furthermore, it is possible for the worker himself to refuse to enter into a written contract, in which case how can the labour inspector order the employer to carry out such a request?

It could be argued that since the fiscal control body has the power to reclassify the earnings of a person as salary income, based on a civil contract, the more this power should be acknowledged to the control body in the field of labour relations to carry out similar reclassification. But the fiscal control body has a set of criteria available - not necessarily the best, but in any case provided directly by fiscal law, and, moreover, it does not requalify the actual contract but reconsiders the income obtained on the basis of the contract. Instead, such a set of criteria is not available for the labour inspector - he may possibly use those provided in the Fiscal Code, but in essence the labour inspector does not directly apply tax legislation.

In addition, the burden that the government's decision is placing on the labour inspector exceeds the task of the fiscal control body: it is the requalification of the contract, an undertaking that is quite difficult, as we have seen, even for the specialized courts.

\section{Requalification of the employment contract as a civil contract}

Although apparently the interest of the parties is rather to name an employment contract between them a "civil contract", sometimes in reality things can be the other way around. Some case-law decisions have proven it. Thus, the High Court of Cassation and Justice ruled by Decision no. 5/2014 (published in the Official Gazette of Romania, Part I, No. 686 of 19 September 2014) on the possibility of requalification of an employment contract.

The High Court of Cassation and Justice had been referred to a question concerning the interpretation of the provisions of Art. 34 para. (7) of the Framework Law on the unitary remuneration of staff paid from public funds no. 284/2010 (published in the Official Gazette of Romania, Part I, No. 877 of 28 
December 2010, now repealed) stipulating that a certain percentage of salary increase "is granted from the date of signing the contract/agreement/financing order by the contracting parties, namely the beneficiary institution and the financing authority, from the date of entry into force of this article." The wording of the text is obviously deficient because it marks two distinct moments from which the salary increase applies: from the date of signing the contract and from the date of entry into force of the law. Thus, in practice, there was the problem of the financing contracts concluded before the date of entry into force of Law no. $284 / 2010$ that had already been signed.

Would those who worked under those contracts benefit or not from the salary increase?

The decision of the Supreme Court was negative, based on the argument that the text can not be retroactively applicable. On that occasion, however, the High Court also carried out a requalification of employment contracts, arguing that: "Contracts, conventions concluded with the specialists involved in projects, although called employment contracts, do not, however, have the typical characteristics of such contracts. On the contrary, their civil legal nature is evident, being specifically concluded in relation to expressly individualized activities and services provided by those specialists within the broad framework of the activities carried out under the project financed by Community funds or external loans, in exchange for a consideration, due payment, negotiated between the parties."

It follows that the court applied criteria based on which it considered that the legal nature of the contract between the parties was that of civil contract rather than employment contract. Unfortunately, the criteria used are not foreign to any employment contract. Indeed, the latter also involve expressly individualized activities and services (it is actually the job description) and a consideration, established by the parties (the salary). What decisively characterizes the civil contract, distinguishing it from the employment contract, is the absence of a relationship of subordination and dependency (Dimitriu, 2017: 567; Ticlea, 2015: 11-12); the contract could have been reclassified as a civil contract only to the extent that the relationship of legal equality between the parties to the contract had been established. Subordination translates into the right of the beneficiary of the work to give instructions on how to perform it (most often: the duration of work, the place where it is provided, the work schedule and the content of the work).

It is not about instructions concerning the work outcome which the beneficiary of an activity performed under a civil contract might also provide. But it is about the right (and obligation) of the beneficiary of work to guide the employee, with two consequences:

- on the one hand, assuming the risk, if the work performed in accordance with the instructions received does not meet expectations; 
- on the other hand, the right to sanction the employee for failure to comply with the orders received from the superior, irrespective of the extent to which the result of the work was or was not as expected.

The criterion of subordination (Panainte, 2017: 6) is reflected in a series of rights of the employer under the employment contract, listed in art. 40 of the Romanian Labour Code; the employer is thus entitled to "establish the organization and functioning of the establishment", "to establish the duties of each employee, in accordance with the law", „to issue orders that are mandatory for the employee, subject to their legality", „to exert control over the manner in which job tasks are carried out".

The court ventured to perform a requalification without highlighting in any way the specifics of the employment contract, in comparison with the civil contract, especially when it concerned written and recorded employment contracts (at the time of the decision, the written form was required ad validitatem).

It is noteworthy, however, that the court has undertaken to overturn the presumption of concordance between the actual legal nature of the contract and its name. In conclusion, the requalification of the contract can be performed in both directions. Not only the court can perform it, but also control bodies - fiscal or labour law - could do the same.

\section{Conclusions}

Finding the inconsistency between the expressed will of the parties and the reality of the legal relationship concluded between them, both the courts and some control bodies can carry out the requalification of the contract (or of the revenues obtained under it). They may find that although a contract is named a civil contract, it is actually an employment contract (or, using the wording of the Fiscal Code, it is an "employment relationship"). Based on the analysis carried out in the preceding pages it can be stated that:

- The requalification was facilitated by the repeal of the requirement of the written form ad validitatem and the return to the consensual nature of the individual employment contract;

- The overturning of the presumption of concordance between the will of the parties and the name of the contract may be performed on the basis of some criteria, which in our legal system only tax legislation expressly establishes. Labour law courts may use - perhaps even more justifiably - the criteria laid down in Recommendation no. 196/2006 of the International Labour Organization;

- The requalification procedure does not differ if the parties have intended to conceal the true legal nature of the contract (the simulation case) or have 
inadvertently entered into a contract other than the one which would have corresponded to their true legal will (the interpretation of the contract according to the concordant will of the parties);

- The requalification carried out by the fiscal control body does not concern the contract itself, but the revenue obtained under it. The decision of the fiscal body is not enforceable either by the labour law court or by the labour inspector. However, it establishes an extremely important indicator for the labour law court called upon to rule in an action determining an employment contract, and all the more so for labour inspectors;

- Requalification by labour inspectors is not based on a set of legal criteria and we can anticipate - this newly introduced task will create difficulties and confusion;

- Requalification can take place in both ways, but it is much less common for the parties to conclude a civil contract and call it a contract of employment.

The current set of regulations on requalification of the employment contract is far from ideal. Therefore, a number of improvements to ensure coherence in the system would be welcome.

Firstly, a number of criteria for identifying the employment contract should be explicitly laid down and included in the labour law. Recommendation no. 196/2006 of the International Labour Organization may be a good source of inspiration, but the criteria listed in it will have to be adapted to the specificities of the Romanian labour market as well as to the recent developments in the employment relationship in general. Thus, the starting point could be the subordination characteristic, decisive in the case of an employment contract and, at the same time, an important element that distinguishes it from the civil contract.

Less emphasis may be placed on the worker's integration into the organization of the enterprise (because the employee can also work from home), the existence of a specific work program (which in the case of the employee it could be individualized), of a specified place (because tele-workes or mobile employees may also lack such established workplaces) or on the condition that the income is the sole source or the main source of income (because the employee may have other sources of income by cumulating several employment contracts).

Instead, the performance of work under the instructions and under the control of the employer, carrying out the activities personally by the worker (without the possibility of using assistants or substitutes), the duration and continuity of work, the provision of tools, materials and equipment by the employer; the regular payment of the worker's remuneration and the absence of financial risk for the worker - are decisive factors in the design of a contract of employment. 
On the other hand, it would be useful to provide in concrete terms the relationship between requalification carried out by the different bodies of the State in order to avoid the situation where a certain relationship is, from a fiscal point of view, an employment relationship but from the point of view of the labour law courts a civil contract.

The possibility for the labour inspector to identify the work relationship, an undertaking which requires subtlety and which only the labour law court could perform, should be revised. And, in any case, the right of the labour inspector to order the conclusion of an employment contract should be removed.

An interesting assumption present in other European legal systems may also be adopted: the assumption that any other contractual arrangement concluded between the employee and the employer, distinct from the employment contract, is also an element of the latter. The idea is that a civil contract can take place between any two persons, including between two people already in an employment contract. However, irrespective of the name given by the parties to this contractual arrangement, the assumption that such an agreement was also concluded in the light of the pre-existing subordination relationship between the parties would apply in this case.

A civil contract between an employee and his employer is presumed to have a simulated nature, and must be treated as a clause of the employment contract. The assumption is relative and can be overthrown by proof that in reality there is no link between the employment relationship and the civil contract.

\section{References}

Baias, F. (2003) Simulaţia, Studiu de doctrină şi jurisprudenţă [Simulation, A Study on Doctrine and Case Law], Rosetti Publishing House, Bucharest

Daugareilh, I. (2011) "Protection of Working Relation in France", in Pennings, F. $\&$ Bosse, C. (Eds.) The Protection of Working Relationship. A Comparative Study, Wolters Kluwer, pp. 61-83

Daubler, W. (2011) "Protection of Working Relationship in Germany", in Pennings, F. \& Bosse, C. (Eds.) The Protection of Working Relationship. A Comparative Study, Wolters Kluwer, pp. 127-143

Dimitriu, R. (2017) “The Concept of 'Employee': The position in Romania”, in ed. Waas, B. \& van Voss G. H. (Eds.) Restatement of Labour Law in Europe, vol. I: The Concept of Employee, Hart Publishing, Oxford and Portland, pp. $557-577$

Dimitriu, R. (2016) Dreptul muncii. Anxietăți ale prezentului [Labour Law. Anxieties of the present], Rentrop și Straton Publishing House, Bucharest 
Dimitriu, R. (2015) "Labour contract disguised into a civil contract", Studii si Cercetari Juridice, vol. 60: 73-91

Gheorghe, M. (2013) Consideratii relative la prestarea disimulata a muncii situatii, cauze, efecte, propuneri [Considerations regarding the dissimulated work - situations, causes, effects, proposals], Dreptul, no. 12: 222-239

ILO (2013) Regulating the employment relationship in Europe: A guide to Recommendation No. 198

Panainte, S. (2017) Dreptul individual al muncii [Individual Labour Law], Hamangiu Publishing House, Bucharest

Rotaru, F. \& Cristescu, S. (2011) Litigii de muncă. Jurisprudenţa relevantă a Curţii de Apel Bucureşti pe semestrul II 2010 [Employment disputes.Relevant case law of the Bucharest Court of Appeal for the second semester of 2010], Hamangiu Publishing House

Rosioru, F, (2012) The changing concept of subordination, https://mtapte.ajk.pte.hu/downloads/felicia_rosioru.pdf [on-line acces: 12 March 2018]

Stătescu, C. \& Bîrsan, C. (1981) Tratat de drept civil [Treatise on Civil Law], Academiei Publishing House

Ștefănescu, I.T. (2017) Tratat teoretic şi practic de dreptul muncii [Theoretical and Practical Treatise on Civil Law], Universul juridic Publishing House

Ticlea, A. (2015) Tratat de dreptul muncii [Treatise on Labour Law], Universul juridic Publishing House

\section{Legislation}

Decision of the High Court of Cassation and Justice no 37/2016, published in the Official Gazette of Romania, Part I, No. 114 of 10 February 2016

Decision of the High Court of Cassation and Justice no. 5/2014, published in the Official Gazette of Romania, Part I, No. 686 of 19 September 2014

Fiscal Code - Law no. 227/2015, published in the Official Gazette of Romania, Part I, No. 688 of 19 September 2015)

Government Emergency Ordinance no. 53/2017, published in the Official Gazette of Romania, Part I, No. 633 of 7 August 2017

Government Emergency Ordinance no. 79/2017, published in the Official Gazette No. 885 of 10 November 2017

Government Decision no. 488/2017 regarding the approval of the Regulation for the organization and functioning of the Labour Inspection, published in the Official Gazette of Romania, Part I, No. 594 of 25 July 2017

Social Dialogue Law no. 62/2011, republished in the Official Gazette of Romania, Part I, No. 625 of 31 August 2012 